\title{
WEB-BASED INQUIRY IN SCIENCE LEARNING: BIBLIOMETRIC ANALYSIS
}

\author{
Pramita Sylvia Dewi $^{1,5}$, Ari Widodo ${ }^{2}$, Diana Rochintaniawati ${ }^{3}$, Eka Cahya Prima ${ }^{4 *}$ \\ ${ }^{1,2,3,4}$ Department of Science Education, Universitas Pendidikan Indonesia, Indonesia \\ ${ }^{5}$ Department of Primary Education, Universitas Lampung, Indonesia \\ *Corresponding author: ekacahyaprima@upi.edu
}

\begin{tabular}{l}
\hline \hline Article Info \\
\hline Article history: \\
Received: June 28, 2021 \\
Accepted: July 13, 2021 \\
Published: July 31, 2021
\end{tabular}

\section{Keywords:}

Bibliometric analysis

Science education

Web-based inquiry

\begin{abstract}
Web-based inquiry is an intermediary medium that supports broad sharing of data and ideas, in visualizing, analyzing, and offering knowledge integration. This study aims to analyze the scope of scientific research related to web-based inquiry using bibliometric studies starting from the last 10 years. Database information is obtained from Scopus indexed papers, via the Publish or Perish application. Based on the search and selection results, 65 articles were obtained which were then reviewed with Zotero and processed with the VOS viewer. The analysis used is based on the title area, according to web-based inquiry in supporting science education research. Overall, this study provides information regarding research opportunities in science learning with web-based inquiry, especially during this pandemic. This research also illustrates the publication opportunities in various countries that have a high interest in the topic of inquiry. The mapping of the bibliometric results also supports the scientific explanation between the theory and the evidence of probability. Therefore, the literature is expected to be a reference for further science research.
\end{abstract}

\section{WEB-BASED INQUIRY PADA PEMBELAJARAN IPA: BIBLIOMETRIK} ANALISIS

\section{Kata Kunci: \\ Analisis bibliometrik \\ Pendidikan IPA \\ Web-based inquiry}

\begin{abstract}
ABSTRAK
Web-based inquiry merupakan media perantara yang mendukung berbagi data dan ide secara luas, baik dalam memvisualisasikan, menganalisis, maupun menawarkan integrasi pengetahuan. Penelitian ini bertujuan untuk menganalisis ruang lingkup penelitian IPA terkait web-based inquiry menggunakan studi bibliometrik dimulai dari 10 tahun terakhir. Informasi database diperoleh dari makalah terindeks Scopus, melalui aplikasi Publish or Perish. Berdasarkan hasil pencarian dan seleksi, didapatkan 65 artikel yang kemudian direview dengan Zotero dan diolah dengan VOS viewer. Analisis yang digunakan berdasarkan area judul, sesuai web-based inquiry dalam mendukung penelitian pendidikan IPA. Secara keseluruhan, studi ini memberikan informasi terkait peluang penelitian pembelajaran IPA dengan inkuiri berbasis web, terutama di masa pandemik ini. Penelitian ini juga menggambarkan peluang publikasi di berbagai negara yang memiliki minat tinggi terhadap topik inkuiri. Pemetaan dari hasil bibliometrik juga mendukung penjelasan ilmiah antara teori dan bukti dari peluang tersebut. Oleh karena itu, literatur diharapkan dapat menjadi acuan bagi penelitian IPA selanjutnya.
\end{abstract}




\section{INTRODUCTION}

Globalization causes developments in various social fields [1], including education, the application of the learning innovation process has changed significantly [2]. This leads to the need for quality and innovative training to leave the traditional teaching-learning approach to a technology-based teaching-learning approach [3]. This reason reinforces that the pedagogical aspect is directed at developing the real application of the training. Field practice will provide a positive value for the progress of students' thinking, also increase students' motivation and satisfaction [4]-[6]. Recently, training and field practice have become a concern for policy makers, teachers, and teaching and learning facilities providers. These reforms must be reviewed in order to find a way to form a new innovation in the learning process [7]. Awareness of the importance of this training arises because technology in this era has a very important role. Therefore, the form of implementation is prioritized to be presented in the learning method [8], [9]. Regarding the role of technology in learning today, technology-based learning has now become the focus of inquiry activities. While in science learning, currently web-based learning is a trend [10]. In addition, several previous studies stated that traditional inquiry learning requires a lot of time, especially to provide feedback for students, so that the role of technology is considered to be able to accommodate actual student inquiry activities.

The use of web-based technology provides a new type of support for inquiry learning, one of which is the web-based inquiry [11]. The support includes tools for synthesizing primary sources [12], sharing data and ideas more widely [13], visualizing and analyzing large amounts of data [14], and offering knowledge integration [15]. If designed properly, the support of these tools can empower learning in the classroom by adding sources of information other than those provided by the teacher. Web-based inquiry is a process of inquiry [16], where support tools on the web are used as a way of inquiry. The web has a function to minimize 'authentic' direct inquiry activities because it does not guarantee that students carry out relevant activities [17]. For this reason, web-based inquiry also includes learning science concepts that cannot be observed directly through direct inquiry learning in the classroom. This kind of learning is very appropriate for current conditions, because right now the world is suffering due to the Covid-19 virus pandemic, the education sector is an area that suffers a lot because face-to-face meetings must be limited [18].

Moreover, web-based inquiry is not only an effective collaborative inquiry learning, but also provides advantages in terms of implementation time and provides space for students to develop confidence and skills to learn science [19]. Meanwhile, the use of technology does not fully fulfill the process skills that students can acquire through direct inquiry learning. Direct inquiry has the advantage of teaching explicit skills when conducting experiments and teachers can find out the depth of students' knowledge and conceptual understanding [20]. Previous research found that the direct inquiry model in the classroom environment provides easier teaching from the teacher's point of view, especially for less experienced teachers [21]. This indicates that this implementation is suitable for use by prospective teachers who are still learning to apply inquiry learning in the classroom [22]. However, the 'efficiency' of direct instruction is not worth the time benefit of web-based inquiry.

Web-based inquiry must be directed in a structured manner and requires good teaching experience and teacher readiness to get maximum learning outcomes [23]. For this reason, in facing the challenges of inquiry-based web learning, understanding is needed to conduct scientific investigations with the help of web-based platform [24] Teacher understanding is also important to assist students in providing additional 
knowledge in distance learning. Lack of understanding and knowledge about inquiry is also the reason why inquiry-based learning is difficult to practice [25]. Therefore, the implementation of effective inquiry-based learning requires good knowledge of pedagogical content. So it is necessary to develop learning that can provide opportunities for students to develop their scientific reasoning abilities [20-23]. Especially with technological advances that provide access tracking networks by providing technical support for information processing [6]. Previous research explained that searches conducted through web devices, in addition to being influenced by cognitive knowledge, are also influenced by students' understanding of concepts, so that students are able to expand new knowledge [26], [27]. In today's digital world, multimedia must be used as a learning medium to prioritize the role of education.

Based on the preliminary explanation presented in this paper, the contribution given is a view of the position of science education on the use of web-based inquiry sourced from bibliometric analysis. The study was conducted on Scopus indexed articles. Tracing analysis was carried out using the Publish or Perish (PoP) application which was then constructed in *RIS format and then imported into the Zotero application. The overall results are then processed with the VOS viewer application, a software for building and visualizing bibliometric networks developed by the Center for the Study of Science and Technology, Leiden University [28]. The bibliometric method is based on examining bibliometric mapping data in scientific publications based on statistical citations [29]. Bibliometric analysis is used as a method to summarize the knowledge and related studies contained in the literature review by measuring certain indicators [30]. Statistically, bibliometrics is associated with an increase in scientific publications from year to year by involving all aspects that contribute and collaborate, such as between authors/institutions, so that the percentage of references per publication can be summarized through the bibliometric method [31], [32]. Furthermore, the bibliometric analysis method has the ability to reveal more detailed data and has a way of presenting data that is easily accessible, because the comparison of the amount of data obtained and the data analyzed is more objective so that it is possible to form new research patterns and themes [33].

The bibliometric analysis in this study analyzes articles that have been published in Scopus indexed articles in the last 10 years. This study also describes the opportunity for web-based inquiry as research that continues to be developed, especially in developed countries, but is rarely developed in Indonesia even though web-based inquiry can support various student learning styles, especially in science learning. Considering the results of various previous studies, this paper provides a broader reference to the literature review on science learning with web-based inquiry, which can later be used for broad-scale subjects. This study illustrates that inquiry has been widely studied, especially related to fostering student learning motivation, and the traditional inquiry learning process. Therefore, science education research with web-based inquiry has a high opportunity to be researched, by anticipating weaknesses and maximizing the role of technology in its implementation. This research can be a reference that web-based inquiry positions itself as an intermediary medium that can be combined with mixed learning. This analysis also shows the variables that are most often associated with web-based inquiry in science learning, so they can be investigated further.

\section{METHOD}

The data used in this study is data from Scopus indexed articles, because Scopus is the largest indexer in the world and has indexed many quality journals from all countries [34]. The VOS viewer is used as a bibliometric analysis tool, while the Publish or Perish 
(PoP) application is used to select literature on studies on science education through webbased inquiry [35]. Gradual use of PoP to describe the search from the initial data to obtain a visual analysis of the results of the investigation [36].

This research was conducted online with the search word "science education through web-based inquiry", with the limitation of the year the article was published is 2011-2021. This limitation is enforced by the Publish or Perish (PoP) application. When searching for Scopus indexed articles, the results are varied, there are articles, book chapters, conference papers, and literature reviews. So it has to be done manually. After manual selection, 65 articles were selected. The selection results in the form of BibTex are then reviewed again using the Zotero application.

After all the data is reviewed, the data is stored in RIS format to be processed with the VOS viewer application [28]. The results of the bibliometric map illustrate the interrelationships between the main search domains, which are represented by interconnected lines and provide visualization [37]. The stage for bibliometric mapping was adopted from the previous research [32], [35], the selection step is shown in Figure 1.

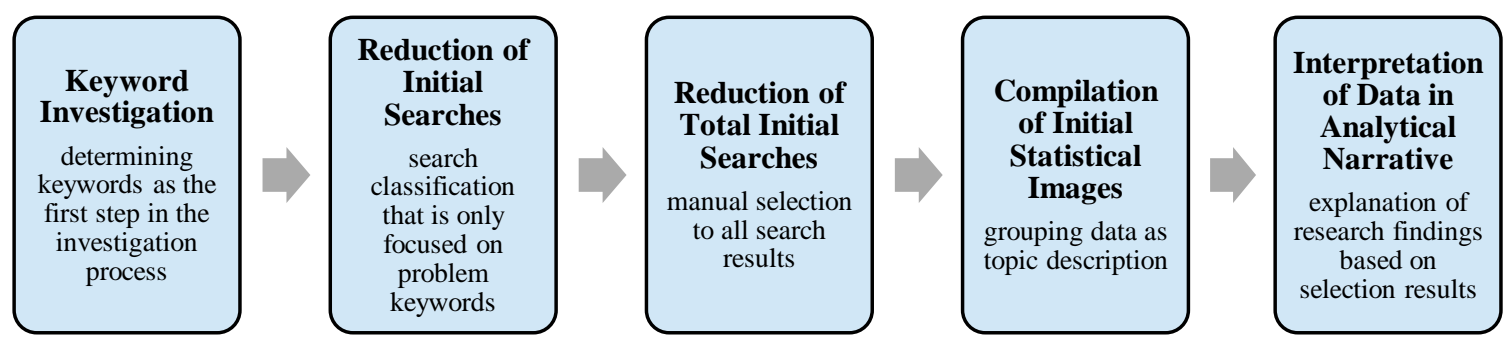

Figure 1. Five Step Bibliometric Analysis Method

\subsection{Keyword Investigation}

Before taking the data, the researcher focused on the problem of inquiry learning, which was characterized by a thought process to achieve a learning goal. Inquiry-based learning is characterized by questions that are the goal of the inquiry process. The relation in compiling and using web-based inquiry must be clear, the intermediary must be designed so that students understand real knowledge of the inquiry learning process, which in this study the role of technology is very dominant. For that, designing the initial idea before learning becomes very important.

\subsection{Reduction of Initial Searches}

After deciding which keywords to use, the researcher conducted a literature review on web-based inquiry in science learning. The use of the Publish or Perish (PoP) application limits the results of the early stage studies to only Scopus indexed journal articles.

\subsection{Reduction of Total Initial Searches}

After obtaining the initial search results, the investigation on Publish or Perish (PoP) is then saved in RIS format. The analysis description explains that it is often the case that the application of inappropriate strategies in inquiry learning on science subjects often occurs. 


\subsection{Compilation of Initial Statistical Images}

In this process, articles that have previously been reduced with Publish or Perish (PoP) are then saved in RIS format and displayed through the Zotero application. With the Zotero application, articles are reviewed for completeness of data.

\subsection{Interpretation of Data in Analytical Narrative}

After all data from Zotero is complete, it can be forwarded to the next process, namely data interpretation. Data interpretation is done with the VOS viewer application. The visualization of the VOS viewer provides data representation in the form of a map of variables related to keywords and has the opportunity to be developed.

\section{RESULTS AND DISCUSSION}

Article search results through the Publish or Perish (PoP) application provide metadata for publication information. Article metadata is collected through the Scopus database with the limitation of the year published in the last 10 years. The metadata of the articles provides details as shown in Table 1.

Table 1. Matric of Metadata Publish or Perish

\begin{tabular}{cc}
\hline Component Data & Initial Search Results \\
\hline Source & 'web-based inquiry' \\
Publication years & $2011-2021$ \\
Citation years & $10(2011-2021)$ \\
Papers & 65 \\
Cititations & 833 \\
Cites/year & 83.30 \\
Cites/paper & 12.62 \\
Author/paper & 0,98 \\
h-index & 14 \\
g-index & 28 \\
h1_norm & 14 \\
H1_annual & 1.40 \\
hA_index & 6 \\
\hline
\end{tabular}

Based on Table 1, it can be seen that the number of articles that will be interpreted in the bibliometric map is 65 articles. Then for the citations, there are 833, which means that the 65 articles have been cited 833 times. Furthermore, the acquisition of h-index (14) and g-index (28) which shows the minimum index number of each publisher. The data in Table 1 displays the metadata of articles from the last 10 years. The reason for choosing articles from the last 10 years is because the newer the year of publication, research related to web-based inquiry for science education also leads to new knowledge construction.

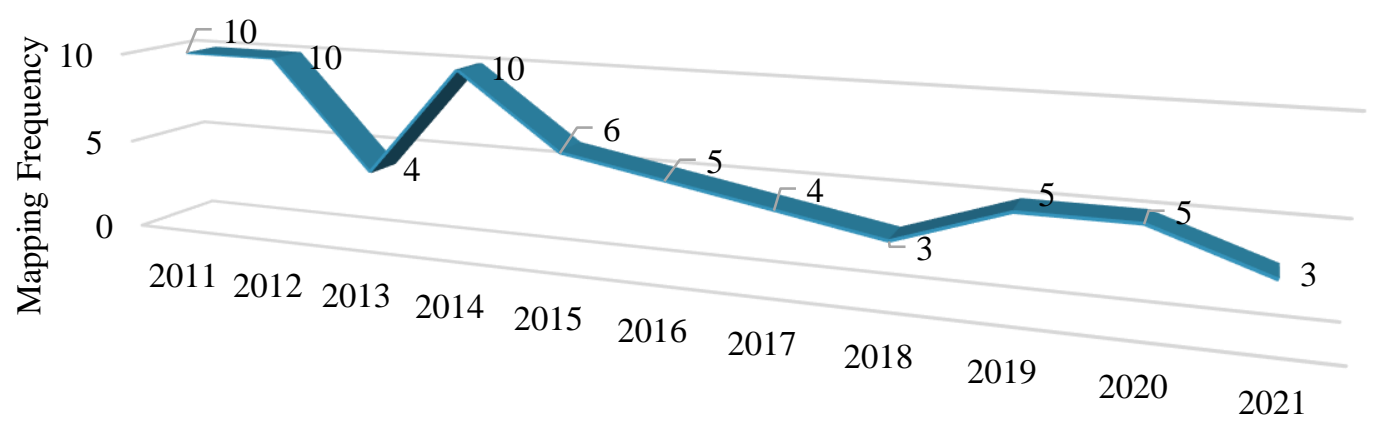

Figure 2. Distribution of Research in the last 10 Years 


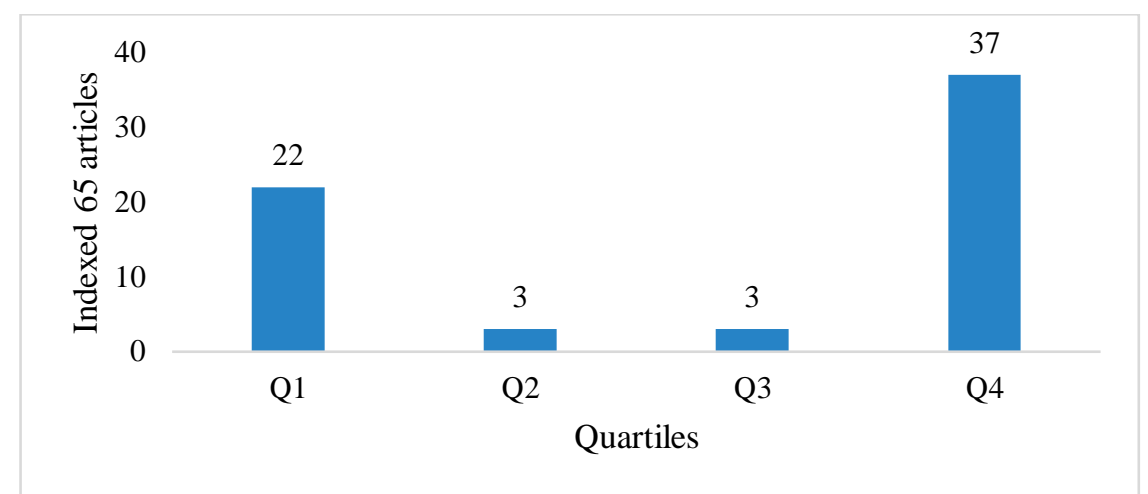

Figure 3. Distribution of Research Based on Quartiles (Scopus)

The results of data analysis are then tabulated and become several graphs as shown in Figure 2 and Figure 3, which present the number of Scopus publications related to webbased inquiry in the period 2011-2021, and the indexation of 65 articles on a quartile scale (Q1-Q4). Figure 2, shows the number of research articles with the theme of web-based inquiry on science learning, the graph shows a decrease in the number of publications, only in 2011, 2012, and 2014 where the number of publications was stable. This shows that research related to web-based inquiry in science learning has a high chance of being carried out again because of the current conditions where the era of education is dominated by technology due to limited movement. The graph in Figure 3 shows that the opportunity for researchers to develop web-based inquiry research in journals with an index of quartile Q1-Q2 is still relatively small when compared to journals in quartile Q4.

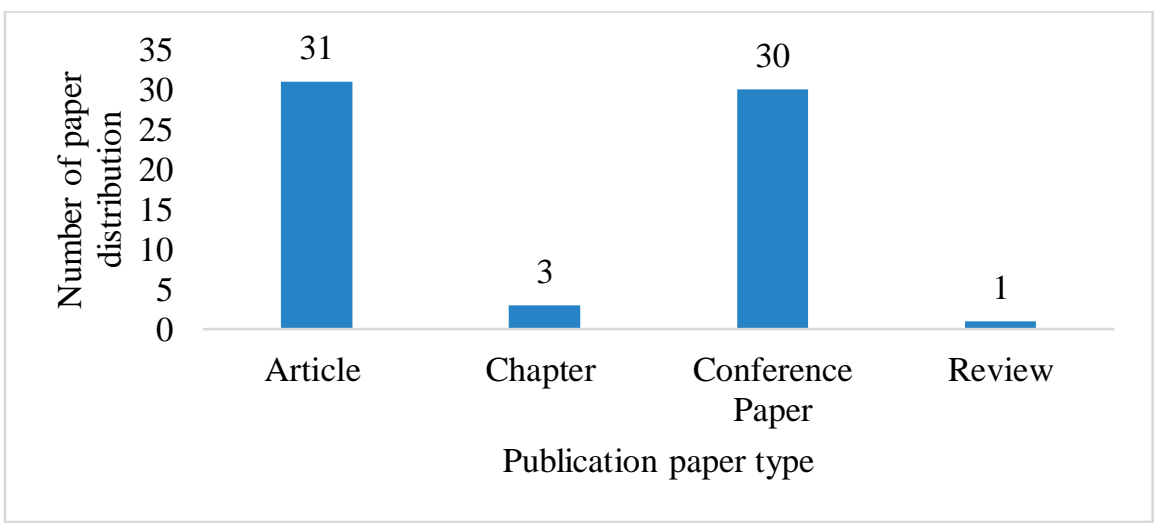

Figure 4. Research Paper Type Distribution

Based on Figure 4, the most published types of documents related to web-based inquiry research in science learning are articles with 31 articles, then conference papers with 30 publications, book chapters with 3 publications and the least is the results of reviews with 1 publication.

Furthermore, the metadata is extracted in the VOS viewer so that it displays the minimum number of occurrences of a term 10, as shown in Table 2. After analysis, there are 101 items, 63 links, and 7 clusters. The first cluster has 26 items, marked in red, the second cluster has 21 items, marked in green, the third cluster has 13 items, marked in dark blue, the fourth cluster has 12 items, marked in yellow, the fifth cluster has 11 items. , marked in purple, the sixth cluster has 10 items, marked in light blue and the seventh cluster has 8 items, marked in orange. Each of these clusters shows the relation between one topic and another which is marked with a different color. 
Table 2. Representation of 7 Color Clusters from a Bibliometric Map

\begin{tabular}{|c|c|c|}
\hline No & Cluster & Keyword \\
\hline 1 & Red & $\begin{array}{l}\text { Achievement, assesment, blended learning environment, computr, design, e- } \\
\text { learning, effect, engagement, environment, factor, impact, instruction, } \\
\text { intercultural competences, learning, literature review, motivation, outcome, } \\
\text { performance, process, relation, relationship, satisfaction, school, self, student, } \\
\text { student engagement. }\end{array}$ \\
\hline 2 & Green & $\begin{array}{l}\text { Analysis, analytic, application, blended learning, competence, context, } \\
\text { development, digital competence, evaluation, evidence, flipped clasroom, } \\
\text { framework, higher education, laguange, perspective, social medium, strategy, } \\
\text { system, teacher education, teaching, use }\end{array}$ \\
\hline 3 & Dark blue & $\begin{array}{l}\text { Child, competency, education, effectiveness, game, level, meta-analysis, nature, } \\
\text { professional development, science, scientific inquiry, sustainable development, } \\
\text { systematic review }\end{array}$ \\
\hline 4 & Yellow & $\begin{array}{l}\text { Challenge, colaborative inquiry, community, experience, inquiry, learner, } \\
\text { pedagogy, problem, reflection, role, tool, web. }\end{array}$ \\
\hline 5 & Purple & $\begin{array}{l}\text { Approach, case, implication, information, literature, practice, research, review, } \\
\text { science education, stem, technology. }\end{array}$ \\
\hline 6 & Light blue & $\begin{array}{l}\text { Attitude, clasroom, ict, implementation, influence, perception, primary school, } \\
\text { study, teacher, training. }\end{array}$ \\
\hline 7 & Orange & Case study, knowledge, model, pre service teacher, project, skill, tpack, video. \\
\hline
\end{tabular}

The VOS viewer can display bibliometric mappings in a variety of visualizations, including network, overlay, and density visualizations [38]. Furthermore, the VOS viewer application displays the interpretation of the data in several parts which are also called clusters. The connecting lines form a bibliometric representation mapping. There are 3 specific relationships in the results of this study. These three relationships are shown in Figure 4, which shows the relationship between research themes, Figure 5, shows the distribution of publications in each year and Figure 6, which shows the frequency of density in the distribution of research.

VOSviewer

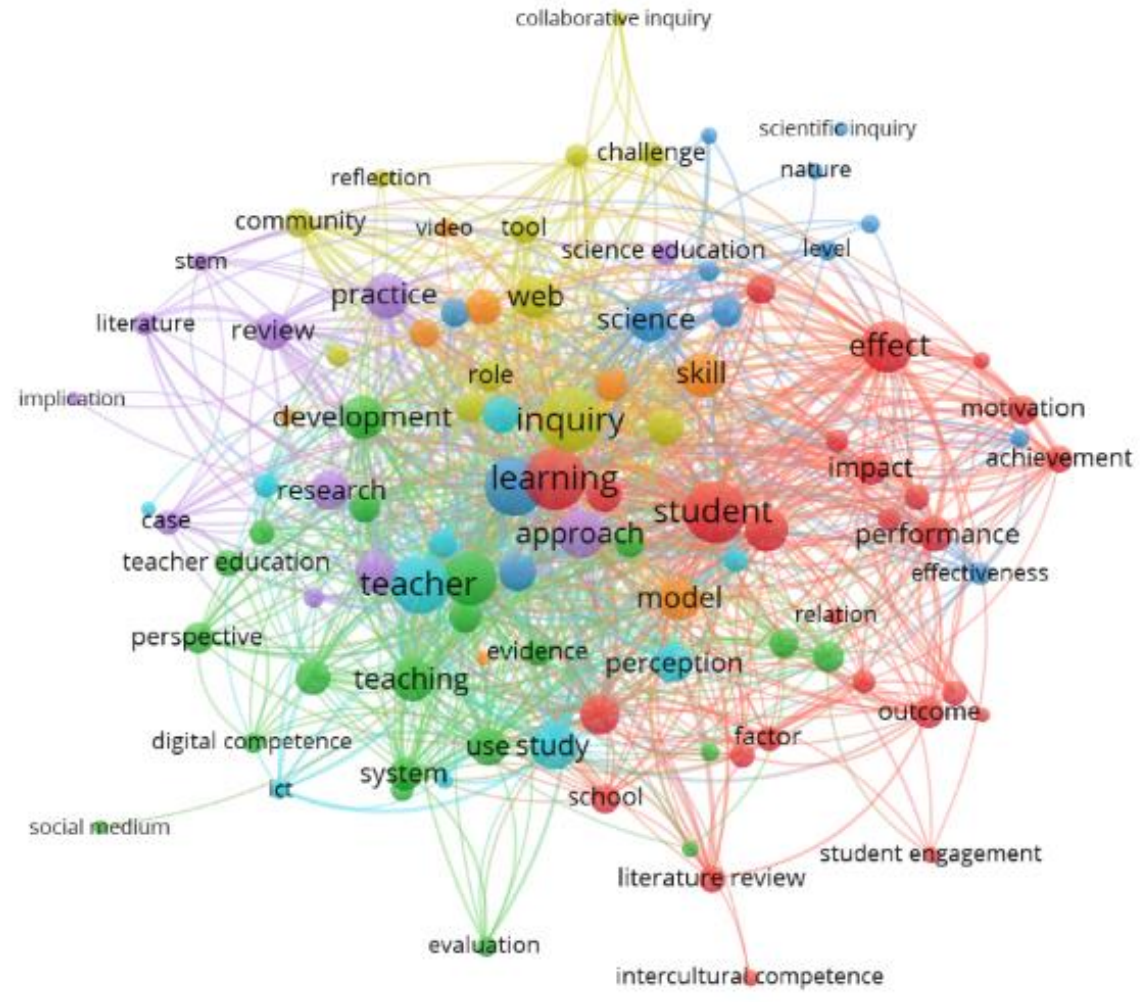

Figure 5. Visualization Topic Area using VOS Viewer (from Scopus Database) 


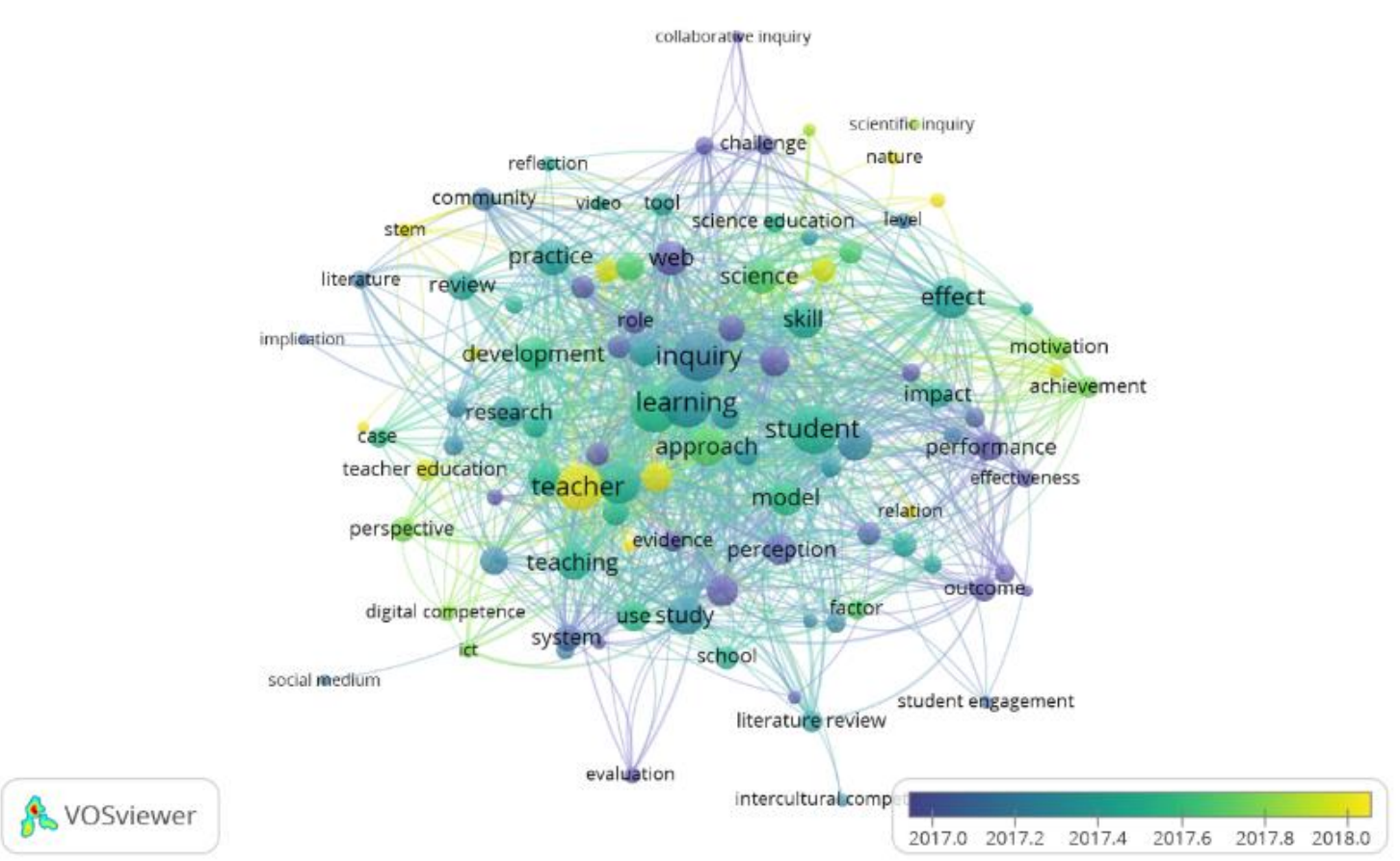

Figure 5. Visualization Topic Area using VOS Viewer, Overlay Visualization (from Scopus Database)

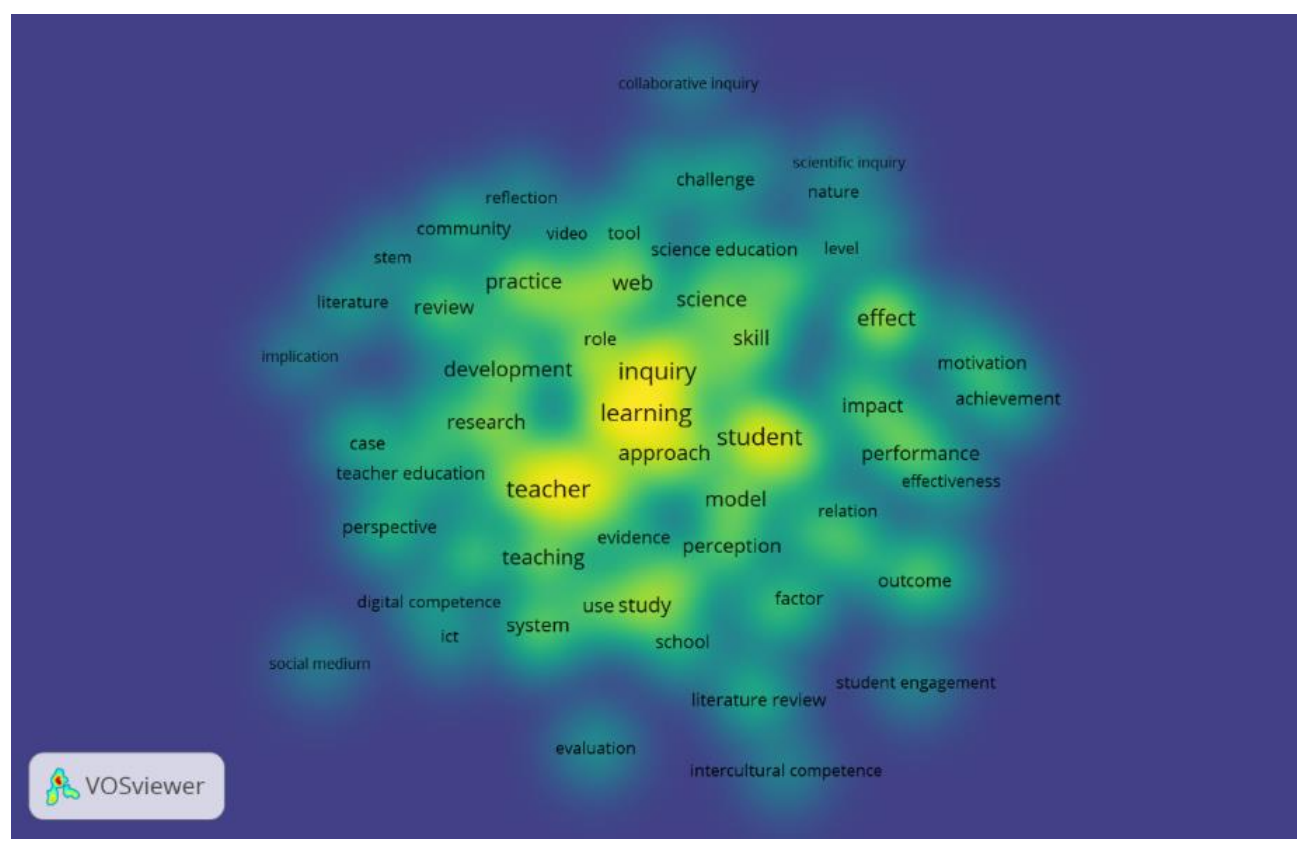

Figure 6. Visualization Topic Area using VOS Viewer using Density Visualization (from Scopus Database)

Based on the results of the interpretation of Figure 4, on the keywords of web-based inquiry in science learning the mapping results provide a very broad picture of related research. Many topics are related to web-based learning and inquiry. Based on Figure 4, it can be seen that technology also takes on the role of implementing a model, where STEM, video, or other simulations, provide a new element of emphasis in science education. Furthermore, in Figure 5, the representation of publications is still dominated by inquiry that requires real practice in schools, but this is an opportunity for further research to develop learning through technology media that has the same effectiveness as face-to-face 
learning. Meanwhile, Figure 6 provides reasons why the practice of teaching teachers through inquiry needs to be developed, because reviews and surveys show that there is a development of teacher competencies that must be expanded with technology. The use of web-based technology may provide a solution to this problem, as it is receiving increasing attention from the science education community, for its potential to provide new types of support for inquiry learning.

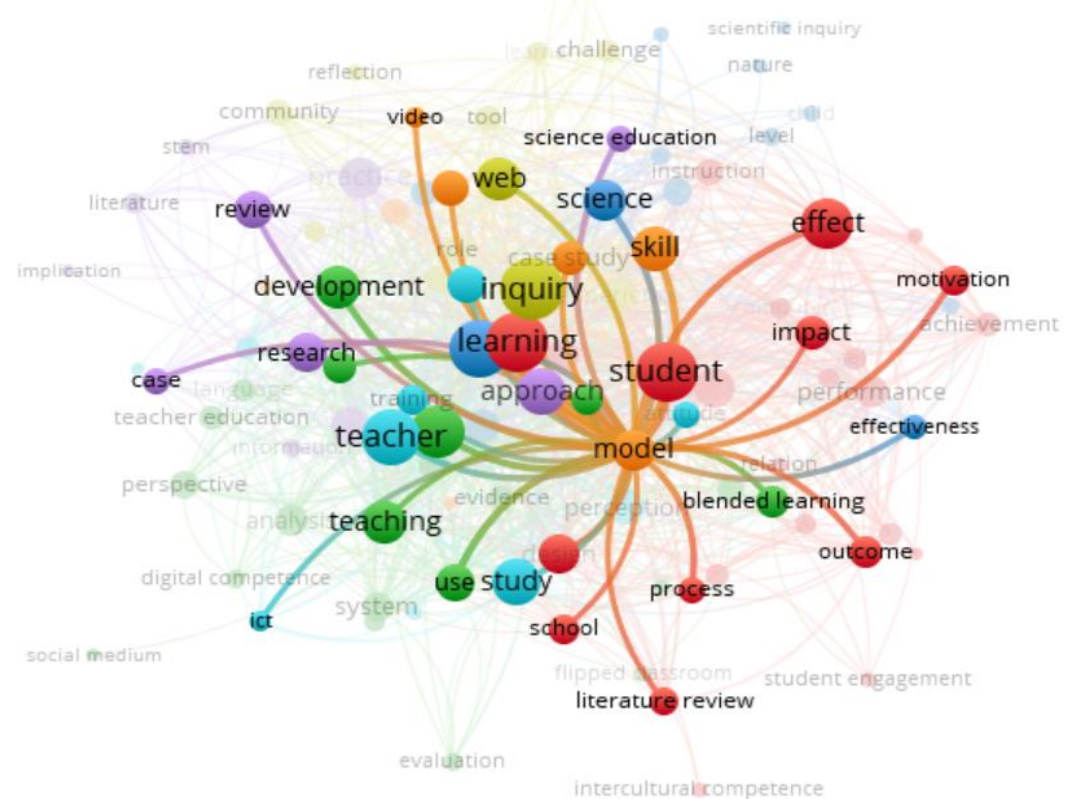

Figure 7. Visualization Topic Area using VOS Viewer Related to Web-based Inquiry in Science Learning

Figures 4, 5, and 6 show the mapping of papers from the Scopus database which clusters research titles related to science research through web-based inquiry, in detail, the display related to these keywords is shown in Figure 7. Based on these details, it is known that science education research related to web-based inquiry is currently very possible to be redeveloped, considering that learning is currently blended or completely online. Figure 3 also states that the density of research on blended learning is not yet visible, this is evidence that the study can still be developed in science education research.

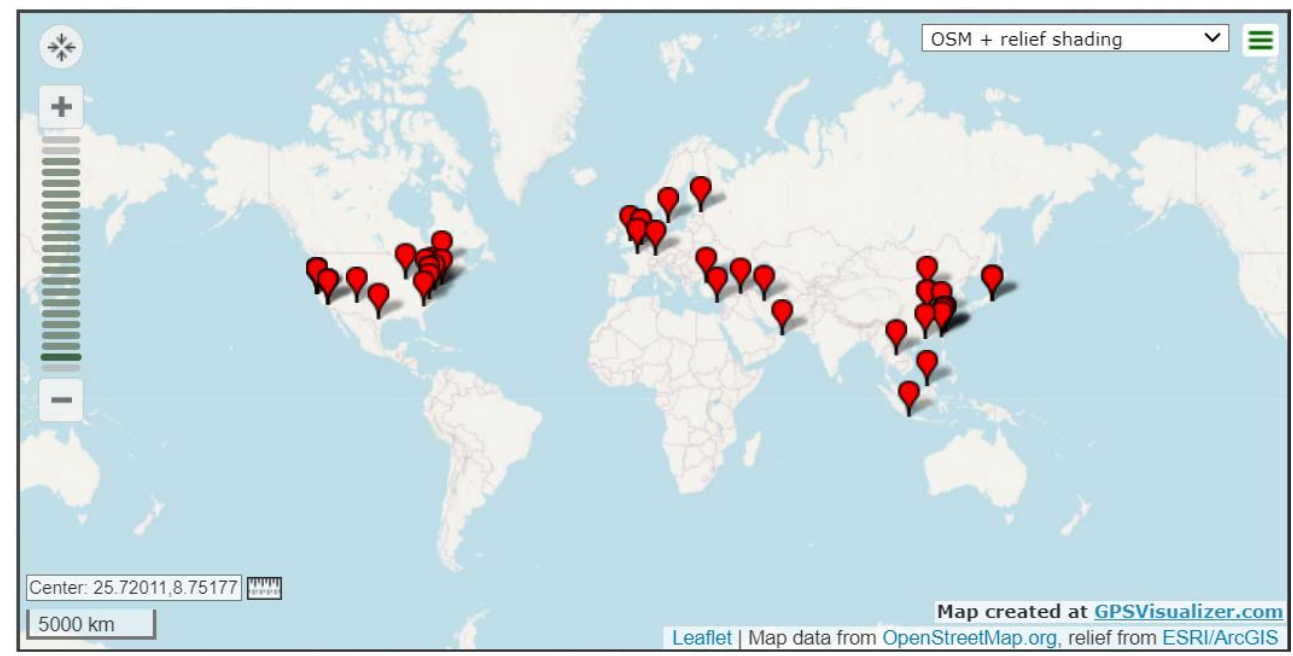

Figure 8. Author Distribution According to City or Country Coordinates 
Figure 8 shows the distribution of origin of the authors of articles related to webbased inquiry, the authors come from various countries and continents. The country that publishes the most articles with the theme of web-based inquiry is the United States, followed by countries from the European continent such as Germany, Belgium, and the United Kingdom. Furthermore, in the Asian region, the countries that have studied the most are Turkey, China, Japan, Oman, Thailand, Taiwan, and Hong Kong. For the Southeast Asian region, only articles from Brunei Darussalam and Indonesia were found. Based on the information from the details in Figure 8, researchers have the opportunity to develop research related to web-based inquiry in Indonesia, because only 1 Scopus article was found. Previous research stated that web-based inquiry still has the opportunity to be reconstructed better, such as development in terms of features and material provision [42]. For this reason, further development is needed considering the usefulness of web-based inquiry as an intermediary medium that strongly supports science learning.

Based on the findings obtained from this study, inquiry-based learning models have been developed by many researchers, one of which is web-based inquiry [26], [27]. Webbased inquiry provides a solution for distance learning because the teacher involves students in learning scientific practice through applications and realistic independent practice. Students gain knowledge from everyday experiences. Inquiry learning emphasizes the use of investigation to critically evaluate evidence, and students are involved in constructing knowledge [16]. In addition, web-based inquiry is not only effective collaborative inquiry, it is also advantageous in terms of execution time because it can be carried out anywhere. Web-based inquiry can also develop students' confidence and skills to learn science [19]. Lack of understanding and experience of teachers in teaching with inquiry can hinder the implementation of web-based inquiry [14], [15]. The problem that is often faced is the lack of understanding of inquiry learning which causes learning strategies to be inappropriate [39]. The way teachers stimulate student activity at school does not make students think critically [40], [45]. Web-based inquiry offers full and in-depth investigative activities [21]. On the other hand, the use of web-based inquiry provides an instructional design that should be followed as a guide. If this design is designed according to an inquiry-oriented process, then effective learning will be very likely to be achieved [16]. Furthermore, web-based inquiry in science learning with diverse student characteristics is possible to become the focus of further research. The publication of articles related to web-based inquiry is growing rapidly in developed countries, but it is still very rare in Indonesia, so that research opportunities for web-based inquiry in science learning with diverse student characteristics are interesting and important topics to be researched.

\section{CONCLUSION}

Learning during a pandemic is very dependent on the role of technology, in this case web-based inquiry is one solution for carrying out science learning. The findings of this study explain the science learning process can not be separated from inquiry which gives students the experience to think critically to solve science problems. The development of web-based inquiry in its reconstruction and its use has not been widely found in Indonesia. Furthermore, web-based inquiry in science learning with diverse student characteristics is possible to become the focus of further research. The publication of articles related to webbased inquiry is growing rapidly in developed countries, but it is still very rare in Indonesia, so that research opportunities for web-based inquiry in science learning with diverse student characteristics are interesting and important topics to be researched. 


\section{REFERENCES}

[1] S. M. Sanahuja, "Teaching innovation projects: fundamental features to their design, implementation and evaluation," Rev. Ciencias Pedagógicas e Innovación, vol. VII, no. 1, pp. 95-103, 2019, [Online]. Available: https://orcid.org/0000-00032935-1202.

[2] S. Supermane, "Transformational leadership and innovation in teaching and learning activities: The mediation e ect of knowledge management.," Inf. Discov. Deliv, vol. 47, pp. 242-250, 2019.

[3] S. Kars-Unluoglu, "How do we educate future innovation managers? Insights on innovation education in MBA syllabi," Innov. Manag. Policy Pract., vol. 18, no. 1, pp. 74-98, 2016, doi: 10.1080/14479338.2016.1187077.

[4] P. A. Ho, C. Girgis, J. K. Rustad, D. Noordsy, and T. A. Stern, "Advancing the Mission of Consultation-Liaison Psychiatry Through Innovation in Teaching," Psychosomatics, vol. 60, no. 6, pp. 539-548, 2019, doi: 10.1016/j.psym.2019.07.007.

[5] N. A. Soltis, K. S. McNeal, C. T. Forbes, and D. Lally, "The relationship between active learning, course innovation, and teaching Earth systems thinking: A structural equation modeling approach," Geosphere, vol. 15, no. 5, pp. 1703-1721, 2019, doi: 10.1130/GES02071.1.

[6] G. Li and F. Wang, "Research on art innovation teaching platform based on data mining algorithm," Cluster Comput., vol. 22, pp. 13867-13872, 2019, doi: 10.1007/s10586-018-2119-x.

[7] N. Van Assche et al., "Guidelines for development of Implant Dentistry in the next 10 years regarding innovation, education, certification, and associations," Clin. Oral Implants Res., vol. 29, no. 6, pp. 568-575, 2018, doi: 10.1111/clr.13154.

[8] C. M. Chou, C. H. Shen, H. C. Hsiao, and T. C. Shen, "Factors influencing teachers' innovative teaching behaviour with information and communication technology (ICT): the mediator role of organisational innovation climate," Educ. Psychol., vol. 39, no. 1, pp. 65-85, 2019, doi: 10.1080/01443410.2018.1520201.

[9] M. N. Campos Soto, M. Ramos Navas-Parejo, and A. J. Moreno Guerrero, "Virtual reality and motivation in the educational context: Bibliometric study of the last twenty years from Scopus," Alteridad-Revista Educ., vol. 15, no. 1, pp. 47-60, 2020, doi: 10.17163/alt.v15n1.2020.04.

[10] P. S. Dewi, D. Rochintaniawati, and S. Parsaoran, "Profiling the context of natural history teacher candidate for the elementary school degree through web-based inquiry," J. Inov. Pendidik. IPA, vol. 6, no. 1, pp. 49-58, 2020, doi: 10.21831/jipi.v6i1.30991.

[11] A. M. Bodzin and W. M. Cates, "Enhancing Preservice Teachers' Understanding of Web-based Scientific Inquiry," J. Sci. Teacher Educ., vol. 14, no. 4, pp. 237-257, 2003, doi: 10.1023/b:jste.0000009549.20273.8a.

[12] M. C. Linn, P. Bell, and S. Hsi, "Lifelong science learning on the Internet: The knowledge integration environment.," Interact. Learn. Environ., vol. 6(1-2), pp. 4 $38,1998$.

[13] A. Feldman, C. Konold, and B. Coulter, Network science, a decade later: The Internet and classroom learning., Mahwah, NJ. 2000.

[14] D. C. Edelson, D. N. Gordin, and R. D. Pea, "Addressing the challenges of inquirybased learning through technology and curriculum design.," J. Learn. Sci., vol. 8(34), pp. 391-450, 1999.

[15] M. C. Linn and S. Hsi, "Computers. Teachers. Peers. Science Learning Partners.," 
NJ: Lawrence Erlbaum Associates., 2000.

[16] A. M. Bodzin, "Implementing Web-Based Scientific Inquiry in Preservice Science Methods Courses," Contemp. Issues Technol. Teach. Educ. (CITE Journal), vol. 5, no. 1, pp. 50-65, 2005, [Online]. Available: https://acces.bibl.ulaval.ca/login?url=https://search.ebscohost.com/login.aspx?dire $\mathrm{ct}=$ true $\& \mathrm{db}=$ eric $\& \mathrm{AN}=\mathrm{EJ} 1080843 \&$ lang $=$ fr $\&$ site $=$ ehost -

live\%0Ahttp://www.citejournal.org/vol5/iss1/general/article1.cfm.

[17] B. P. Woolf et al., "A general platform for inquiry learning," Springer, vol. 2363, pp. 681-697, 2002, doi: 10.1007/3-540-47987-2_69.

[18] L. Meng, F. Hua, and Z. Bian, "Coronavirus Disease 2019 (COVID-19): Emerging and Future Challenges for Dental and Oral Medicine," J. Dent. Res., vol. 99, no. 5, pp. 481-487, 2020, doi: 10.1177/0022034520914246.

[19] A. Raes, T. Schellens, and B. De Wever, "Web-based Collaborative Inquiry to Bridge Gaps in Secondary Science Education," J. Learn. Sci., vol. 23, no. 3, pp. 316-347, 2014, doi: 10.1080/10508406.2013.836656.

[20] D. Llewellyn, Inquiry within: Implementing inquiry-based science standards in Grades 3-8. Thousand Oaks, CA: Corwin Press., 2007.

[21] W. W. Cobern et al., "Experimental comparison of inquiry and direct instruction in science," Res. Sci. Technol. Educ., vol. 28, no. 1, pp. 81-96, 2010, doi: 10.1080/02635140903513599.

[22] D. Llewellyn, Inquiry within: Implementing inquiry-based science standards. USA: Corwinn Press, Inc., 2014.

[23] G. Silm, K. Tiitsaar, M. Pedaste, Z. Zacharia, and M. Papaevripidou, "Teachers' Readiness to Use Inquiry-Based Learning: An Investigation of Teachers' Sense of Efficacy and Attitudes toward Inquiry-Based Learning.," Sci. Educ. Int., vol. 28, no. 4, pp. 315-325, 2017.

[24] R. D. Truya and J. Bellen, "Undergraduate Students ' Experiences of Scientific Inquiry in a Web-Based Environment : A Descriptive Phenomenological Study," no. January, 2020.

[25] D. K. Capps and B. A. Crawford, "Inquiry-Based Instruction and Teaching About Nature of Science: Are They Happening?," J. Sci. Teacher Educ., vol. 24, no. 3, pp. 497-526, 2013, doi: 10.1007/s10972-012-9314-z.

[26] G. E. Glasson, "The effects of hands-on and teacher demonstration laboratory methods on science achievement in relation to reasoning ability and prior knowledge," J. Res. Sci. Teach., vol. 26, no. 2, pp. 121-131, 1989, doi: 10.1002/tea.3660260204.

[27] S. Olson, S., \& Loucks-Horsley, Inquiry and the national science education standards: A guide for teaching and learning. Washington, DC: National Academy Press., 2000.

[28] D. Cairns and S. Areepattamannil, "Exploring the Relations of Inquiry-Based Teaching to Science Achievement and Dispositions in 54 Countries," Res. Sci. Educ., vol. 49, no. 1, 2019, doi: 10.1007/s11165-017-9639-x.

[29] D. G. Brenner et al., "Modeling Student Learning Behavior Patterns in an Online Science Inquiry Environment," Technol. Knowl. Learn., vol. 22, no. 3, pp. 405-425, 2017, doi: 10.1007/s10758-017-9325-0.

[30] S. Becker, P. Klein, A. Gößling, and J. Kuhn, "Using mobile devices to enhance inquiry-based learning processes," Learn. Instr., vol. 69, no. April, p. 101350, 2020, doi: 10.1016/j.learninstruc.2020.101350.

[31] Van Eck NJ and W. L, "VOS viewer." Leiden: Univeristeit Leiden, p. pp.1-53., 
2013.

[32] M. Gutiérrez-Salcedo, M. Á. Martínez, J. A. Moral-Munoz, E. Herrera-Viedma, and M. J. Cobo, "Some bibliometric procedures for analyzing and evaluating research fields," Appl. Intell., vol. 48, no. 5, pp. 1275-1287, 2018, doi: 10.1007/s10489-017$1105-\mathrm{y}$

[33] A. Kovács, B. Van Looy, and B. Cassiman, "Exploring the scope of open innovation: a bibliometric review of a decade of research," Scientometrics, vol. 104, no. 3, pp. 951-983, 2015, doi: 10.1007/s11192-015-1628-0.

[34] W. Glänzel, "The role of core documents in bibliometric network analysis and their relation with h-type indices," Scientometrics, vol. 93, no. 1, pp. 113-123, 2012, doi: 10.1007/s11192-012-0639-3.

[35] W. Glänzel and B. Thijs, "Using 'core documents' for the representation of clusters and topics," Scientometrics, vol. 88, no. 1, pp. 297-309, 2011, doi: 10.1007/s11192011-0347-4.

[36] C. Michael Hall, "Publish and perish? Bibliometric analysis, journal ranking and the assessment of research quality in tourism," Tour. Manag., vol. 32, no. 1, pp. 1627, 2011, doi: 10.1016/j.tourman.2010.07.001.

[37] J. C. Valderrama-Zurián, R. Aguilar-Moya, D. Melero-Fuentes, and R. AleixandreBenavent, "A systematic analysis of duplicate records in Scopus," J. Informetr., vol. 9, no. 3, pp. 570-576, 2015, doi: 10.1016/j.joi.2015.05.002.

[38] A. Baneyx, "Publish or Perish' as citation metrics used to analyze scientific output in the humanities: International case studies in economics, geography, social sciences, philosophy, and history," Arch. Immunol. Ther. Exp. (Warsz)., vol. 56, no. 6, pp. 363-371, 2008, doi: 10.1007/s00005-008-0043-0.

[39] I. Setyaningsih and N. Indarti, "Bibliometric analysis of the term " green manufacturing ' Ira Setyaningsih * and Nurul Indarti Ferry Jie," Int. J. Manag. Concepts Philos., vol. 11, no. 3, 2018.

[40] N. J. van Eck and L. Waltman, "Software survey: VOSviewer, a computer program for bibliometric mapping," Scientometrics, vol. 84, no. 2, pp. 523-538, 2010, doi: 10.1007/s11192-009-0146-3.

[41] D. Tranfield, D. Denyer, and P. Smart, "Towards a Methodology for Developing Evidence-Informed Management Knowledge by Means of Systematic Review*," Br. J. Manag., vol. 14, pp. 207-222, 2003, doi: 10.1080/16258312.2014.11517339.

[42] A. I. Yasin, D. Rochintaniawati, and E. C. Prima, "The development of web based inquiry as online science inquiry environment," J. Phys. Conf. Ser., vol. 1806, no. 1, 2021, doi: 10.1088/1742-6596/1806/1/012141.

[43] A. García-Carmona, "Pre-service Primary Science Teachers' Abilities for Solving a Measurement Problem Through Inquiry," Int. J. Sci. Math. Educ., vol. 17, no. 1, 2019, doi: 10.1007/s10763-017-9858-7.

[44] L. Uiterwijk-Luijk, M. Krüger, B. Zijlstra, and M. Volman, "Teachers' role in stimulating students' inquiry habit of mind in primary schools," Teach. Teach. Educ., vol. 86, p. 102894, 2019, doi: 10.1016/j.tate.2019.102894.

[45] A. Widodo, "Peningkatan Kemampuan Mahasiswa PGSD dalam Mengajukan Pertanyaan Produktif untuk Mendukung Pembelajaran IPA Berbasis Inkuiri," J. Pendidik., vol. 1, no. 10, pp. 21-29, 2009. 